\title{
Nutritional and Safety Evaluation of Heat-Stabilized Rice Bran for Supplementary Feeding of Malnourished Children in Kenya
}

John N. Kinyuru ${ }^{1,2}$, Erica C. Borresen², Elizabeth P. Ryan²

${ }^{1}$ Faculty of Agriculture, Department of Food Science and Technology, Jomo Kenyatta University of Agriculture and Technology, Nairobi, Kenya. ${ }^{2}$ Department of Environmental and Radiological Health Sciences, Colorado State University, Fort Collins, Colorado, USA.

\begin{abstract}
Rice bran is a by-product of rice milling that has been primarily used in animal feed negating its potential for human consumption. The aim of this study was to evaluate the application of rice bran to aid in managing infant and childhood malnutrition. Rice bran samples were collected from Kenya (Mwea) and U.S. (RiBran 300, RiceBran Technologies ${ }^{\mathrm{TM}}$ ) for nutritional, heavy metals and microbial analysis. Reference values for rice bran from the USDA nutrient database were included for comparison. Additionally, seven supplementary foods containing maize, soya bean, rice bran and sugar (CSR) for 12-24 month old moderately malnourished children were formulated using nutritional software programs. A $100 \mathrm{~g}$ of Mew rice bran contained $349 \mathrm{kcal}, 20 \mathrm{~g}$ dietary fibre, $19 \mathrm{~g}$ fat, $13 \mathrm{~g}$ protein, $7.5 \mathrm{mg}$ iron and $4.6 \mathrm{mg}$ zinc. A $100 \mathrm{~g}$ of RiBran 300 comprised of $359 \mathrm{kcal}, 25 \mathrm{~g}$ dietary fibre, $22 \mathrm{~g}$ fat, $14 \mathrm{~g}$ protein, $9.7 \mathrm{mg}$ iron and $5.3 \mathrm{mg}$ zinc. Mwea rice bran had $0.12 \mathrm{ppm}$ total arsenic while RiBran 300 had 0.86ppm total arsenic. Both rice brans tested negative for E. coli O-157 and Salmonella spp. The computer simulated CSRs showed that nutrient density increased as rice bran was included ranging from $1-30 \mathrm{~g} / \mathrm{day}$ serving. The retail cost of the CSR's was 38-46 \% lower than Corn-Soya-Blend plus (super cereal) and 65-70\% lower than Corn-Soya-Blend plus plus (Super cereal plus) supplementary foods available in Kenya. These findings indicate that rice bran has the potential to be a nutritious, safe and affordable food ingredient that enhances food and nutrition security.
\end{abstract}

Keywords: Rice Bran; Micronutrient; Supplementary Feeding; Malnutrition; Global Health.

\section{*Corresponding Author:}

Elizabeth P. Ryan,

Department of Environmental and Radiological Health Sciences, Colorado State University, Fort Collins, Colorado 80523, USA.

E-mail: E.P.Ryan@colostate.edu

Received: September 09, 2015

Accepted: November 07, 2015

Published: November 12, 2015

Citation: John N. Kinyuru, Erica C. Borresen, Elizabeth P. Ryan (2015) Nutritional and Safety Evaluation of Heat-Stabilized Rice Bran for Supplementary Feeding of Malnourished Children in Kenya. Int J Food Sci Nutr Diet. 04(6), 226-232. doi: http://dx.doi.org/10.19070/23263350-1500041

Copyright: Elizabeth P. Ryan ${ }^{\circ} 2015$. This is an open-access article distributed under the terms of the Creative Commons Attribution License, which permits unrestricted use, distribution and reproduction in any medium, provided the original author and source are credited.

\section{Introduction}

Global rice production figures indicate that rice is an important source of calories and other important phytonutrients for human health [1, 2]. The 2014-2015 Food and Agriculture Organization (FAO) paddy forecast showed a production of 745 million tonnes of rice paddy which translates to 497 million tonnes of milled rice [3]. This is a $2 \%$ increase from the $2012-2013$ amounts [4]. Even though there has been reports of stagnated rice production in some African countries, Kenya experienced an upward trend of rice production since 1960 [5]. Rice is one of the staple foods in
Kenya primarily grown under irrigation. Kenya produces about 50,000 metric tonnes (MT) of white rice, while the annual consumption is roughly 300,000 MT [6]. To cover the deficit, Kenya imports a majority of rice from Asian countries, such as India and Thailand [7].

Although there is growing evidence for health benefits of whole grain brown rice, most countries around the world consume milled white rice $[8,9]$. Rice bran is an agricultural by-product of rice milling and it constitutes $\sim 10 \%$ of the total whole grain weight $[10,11]$. Kenya's current production of white rice leads to 5,000 MT of rice bran produced per year; most of which is utilized as animal feed and has therefore not received attention by advocates of food and nutrition security programmes. A 2012 report on rice production incentives and disincentives in Kenya [7] and the FAO Rice Monitor reports failed to include any information on rice bran $[3,4]$. Rice bran is a rich source of nutrients and phytochemicals with varied health benefits and could directly tackle malnutrition, across the lifespan, especially in young Kenyan children $[1,2]$.

Biochemical components that are important for promoting nutrition and gut health have been identified in bran across geographically different rice varieties, including oligosaccharides, non-starch carbohydrates (e.g. arabinoxylan and $\beta$-glucagon), phenolics (e.g. ferulic acid), specific fatty acids, vitamin $E$ isomers, $\gamma$-oryzanol and sterols $[9,13,14]$. Rice bran consumption has been shown to increase probiotic gut microbes among humans, as well as branched chain fatty acids and secondary bile acids that are life supporting bio-components [2]. Additionally, rice bran has induced microbial 
changes that contribute to enhanced gut mucosal immunity and protection against diarrhoea in animal studies [15-17].

While there has been extensive research on the health improvements and disease fighting properties from eating rice bran in adult and animal studies, little is known about how rice bran can be utilized in nutritional interventions aimed to prevent or even correct faltered growth in children. Malnutrition, as measured by growth, is a global challenge with stunting affecting an average of $27 \%$ of children under 5 years of age in low or middle income countries [18], and Kenya falls within that average [12]. Levels of stunting are highest at ages between 12-24 months [12]. Growth faltering may be a result of inadequate nutrition and/or associated pathological effects of the gut [19]. Stunting has been associated with impaired gut microbiota [18] and chronic inflammation $[20,21]$, and exists in low income countries with compromised levels of safe water, sanitation and health [22]. To mitigate malnutrition, infant and young children feeding practices should include food ingredients that will not only help meet basic nutrition, but also promote gut health and immune system support during the supplementary feeding period. This will even be more critical to moderately malnourished who require supplementary feeding to ensure quick recovery and prevent cases of malnutrition relapse. Preferably, food ingredients for supplementary feeding should be locally produced, readily available and affordable [23]. Currently, the World Food Programme (WFP) has promoted cornsoy-blends (CSB) which are food supplements utilized to manage moderate acute malnutrition (MAM), but these food blends are not sustainable due to total cost and availability [24]. We hypothesise that locally produced Kenyan rice bran can be a sustainable food ingredient that can aid in managing childhood malnutrition.

The objective of this paper was to evaluate the nutritional and safety profiles, as well as the cost of rice bran obtained from large and small-scale commercial millers in Kenya and compare to a United States (U.S.) commercial rice bran. We also evaluated the nutritional values and cost of novel rice bran based supplementary foods formulated using computer-based software programs as food models for MAM management among 12-24 month old children.

\section{Materials and Methods}

\section{Rice Bran Collection and Stabilization}

Rice bran was collected from three commercial millers within Mwea rice irrigation scheme located in Mwea District of Kirinyaga County in Central Kenya. The bran was freshly milled (within $1 \mathrm{hr}$ ) and was collected during polishing in clean polythene bags. The bran was from a mixed variety of the Basmati long grain rice grown in this location. The bran was heat stabilized within two hours of milling by heating in a microwave at $100^{\circ} \mathrm{C}$ for 5 minutes. It was then cooled to room temperature, re-packed in airtight containers and stored in a dry, cool place with minimal temperature fluctuations. Commercial heat-stabilized rice bran from the U.S., (RiBran 300), was donated from RiceBran Technologies $^{\text {TM }}$ (Scottsdale, AZ). This is a human food grade ingredient, sold as a nutritional supplement and for animal nutrition. The samples were stored in a cool, dry place until analysis. The retail cost information for the bran varieties was obtained directly from the millers.

\section{Nutritional, Microbial and Heavy Metal Analysis}

All nutritional, microbial and heavy metal laboratory tests were completed using standardized and published methods at IEHWarren Analytical Laboratory, (Greeley, CO). The nutritional tests included moisture by air oven drying AOAC 950.46 method, protein by AOAC 992.15/992.23/992.15 (LECO) method, total fat by AOAC 945.44 method, ash by AOAC 920.153 method, total carbohydrates was estimated by difference calculation method (CH029.01), dietary fibre by AOAC 991.43 method, sugars by AOAC 980.13/WRE 004 method, iron by WRE 063 method, zinc by AOAC 2011.14 method, saturated fat by AOAC 996.06 method, trans-fat by AOAC 996.06 method, calcium by EPA 6020 method, sodium by WRE 063 method, vitamin A by WRE 054 method, vitamin C by AOAC 984.26/WRE017 method and calories were calculated using Atwater factors [25]. Salmonella spp. was tested by AOAC-RI PTM 100701 method, total enteric count by AOAC 2003.01 (MB219.02) method, yeasts and mold count by AOAC 997.02 (MB258) method and E. coli O157 was tested by AOAC-RI PTM 100701. Heavy metals arsenic, cadmium, lead were tested by ETA 620 method.

\section{Simulation Modelling of Rice Bran Supplementary Foods}

Corn-Soy-Rice bran (CSR) blends targeting MAM 12-24 months old were modelled using Nutrisurvey ${ }^{\mathrm{TM}}$ (Hohenheim, Germany) and Nutritionists $\operatorname{Pro}^{\mathrm{TM}}$ (Redwood, WA, USA) software programs. The formulations were optimized by linear programming of $\mathrm{Nu}$ trisurvey using the nutrition restrictions based on WHO guidelines $[26,27]$ and proposed energy density and daily consumption amounts for complementary foods $[28,29]$ to achieve highest nutritional value at the most affordable cost possible. The CSR blends were modelled to mimic corn-soy-blends (CSB), which are considered the golden standard for management of MAM that is currently distributed by the World Food Programme (WFP) and other humanitarian organizations. The nutritional profiles of the model CSR blends were compared to CSB + (Super cereal) [30] and $\mathrm{CSB}++$ (Super cereal plus) [31].

The ingredients of the CSR modelled foods included whole white corn, whole soya bean, heat-stabilized rice bran, and sugar. All the ingredients, except rice bran, are the core ingredients in CSB supplementary foods.

\section{Cost Estimation of the Simulated Foods}

The cost of ingredients was based on the prevailing Kenyan markets in Mwea market of Mwea District at the time of sample collection. Using the linear programming module of the $\mathrm{Nu}$ trisurvey $^{\mathrm{TM}}$ software, cost of the food ingredients was calculated for a daily serving. The final retail cost of each CSR blend was calculated by addition of $50 \%$ of the cost of ingredients to cover production, packaging, indirect costs and profit $[32,33]$.

\section{Data Analysis and Presentation}

Nutritional values were compared to values in the United States Department of Agriculture (USDA) nutrient database [34] for crude rice bran, while microbial and heavy metal levels were compared to set regulations for foods by United States Food and Drug 
Administration (FDA), USA, United States Environmental Protection Agency (EPA) and Kenya Bureau of Standards (KEBS). Nutrient values of the modelled CSR blends were compared to Daily Recommended Intakes (DRI) for 12-24 month old children $[35,36]$. Production and retail costs of the CSR blends was compared to the costs of $\mathrm{CSB}+[30]$ and $\mathrm{CSB}++[31]$.

\section{Results and Discussion}

\section{Rice Bran Nutrients, Heavy Metals, Microbial Contents and Cost}

Selected nutrient composition of the U.S. and Kenyan rice bran samples were compared to USDA values for crude rice bran (Table 1). Similarities in the nutritional profiles were found between the Mwea and RiBran 300 rice brans. Clear differences were detected in the energy content with the RiBran 300 having 359.85
$\mathrm{Kcal} / 100 \mathrm{~g}$ and the USDA value being $316 \mathrm{Kcal} / 100 \mathrm{~g}$. Dietary fibre values ranged between 19.8 - 25.8g/100g supporting that rice bran could provide a natural source of dietary fibre in human diet. The total carbohydrate content was similar across the three rice bran samples. Rice bran is also a rich source of fat $(18.98-22.47$ $\mathrm{g} / 100 \mathrm{~g}$ ) with $\sim 4.06 \mathrm{~g} / 100 \mathrm{~g}$ being saturated fats. The protein content ranged from $13.35 \mathrm{~g} / 100 \mathrm{~g}$ in USDA value to $14.43 \mathrm{~g} / 100 \mathrm{~g}$ in RiBran 300. The levels of ash reported $(8.23-9.98 \mathrm{~g} / 100 \mathrm{~g})$ is an indication that rice bran could be a source of minerals that could be of public health significance. USDA rice bran value for iron $(18.54 \mathrm{mg} / 100 \mathrm{~g})$ was two times higher than the values in Mwea (7.50mg/100g) and RiBran $300(9.70 \mathrm{mg} / 100 \mathrm{~g})$. The rice brans were rich in iron and could possibly be used in the management of iron deficiency anaemia, which is endemic in most developing countries [37]. In Kenya, pre-school children are a high risk group [38]. The USDA did not report any values for Vitamin A, however, Mwea and RiBran 300 rice bran samples measured 280

Table 1. Nutritional quality of heat-stabilized rice bran collected from two different geographical regions, compared to USDA database.

\begin{tabular}{|l|l|l|l|}
\hline Component (100g) & Mwea & RiBran 300 & USDA* \\
\hline Proximate & 6.75 & 3.7 & 6.13 \\
\hline Moisture (g) & 349.22 & 359.85 & 316 \\
\hline Energy (kcal) & 51 & 51 & 49.69 \\
\hline Total carbohydrate (g) & 19.8 & 25.8 & 21 \\
\hline Dietary fibre (g) & 6.6 & 9.7 & 0.9 \\
\hline Sugar (g) & 13.4 & 14.43 & 13.35 \\
\hline Protein (g) & 18.98 & 22.47 & 20.85 \\
\hline Total fat (g) & 4.06 & 3.59 & 4.17 \\
\hline Saturated fat (g) & 9.13 & 8.23 & 9.98 \\
\hline Ash (g) & \multicolumn{2}{l}{} \\
\hline Minerals and vitamins (100g) & 6.7 & 3.9 & 5 \\
\hline Sodium (mg/100g) & 52 & 43 & 57 \\
\hline Calcium (mg/100g) & 7.5 & 9.7 & 18.54 \\
\hline Iron (mg/100g) & 4.6 & 5.3 & 6.4 \\
\hline Zinc (mg/100g) & 280 & 280 & 0 \\
\hline Vitamin A (IU/100g) & $<0.1$ & $<0.1$ & 0 \\
\hline Vitamin C (mg/100g) & \multicolumn{2}{|l}{} \\
\hline
\end{tabular}

$*$ USDA nutrient database [34]

Table 2. Heavy metal and microbial safety and cost of heat-stabilized rice bran collected from two different geographical regions.

\begin{tabular}{|c|c|c|}
\hline Component & Mwea & RiBran 300 \\
\hline \multicolumn{3}{|l|}{ Heavy Metals } \\
\hline Arsenic (ppm) & 0.12 & 0.86 \\
\hline Cadmium (ppm) & $<0.1$ & $<0.1$ \\
\hline Lead (ppm) & $<0.1$ & $<0.1$ \\
\hline \multicolumn{3}{|l|}{ Microorganisms } \\
\hline Total enteric count (CFU/g) & 900 & 10 \\
\hline Salmonella spp. & Negative & Negative \\
\hline E. Coli O-157 & Negative & Negative \\
\hline Yeast and mold (CFU/g) & 4300 & $<100$ \\
\hline Cost (US\$/Kg) & $0.12-0.15$ & $1.33-1.62$ \\
\hline
\end{tabular}

FDA and Kenya Bureau of Standards (KEBS) regulations: Salmonella and E-Coli - Nil, Yeast and molds in foods - <100,000 CFU/g 
$\mathrm{IU} / 100 \mathrm{~g}$ of vitamin A.

Cadmium and lead were below 0.1ppm in Mwea and RiBran 300 rice brans (Table 2). However, Mwea rice bran had $0.12 \mathrm{ppm}$ of total arsenic, while RiBran 300 rice bran had $0.86 \mathrm{ppm}$ of arsenic. We have not come across FDA recommendations on arsenic in rice bran, however data in this study show that total heavy metal contents from Kenyan rice bran is lower compared to rice bran from the U.S. Rice accumulates more arsenic than other cereal crops with brown rice having higher levels than polished rice [39]. In a study on rice bran from Japan, arsenic levels ranged from 0.71-1.98ppm [40] signifying that the challenge is global. Heat-stabilized bran was microbiologically safe with the indicator microorganism tested being below required limits in foods. Salmonella spp. and E-coli O-157 were not detected in any of the samples. Both FDA and KEBS recommend that no colony forming units of Salmonella spp. or E-coli O-157 should be detected in foods; hence the rice bran samples in this study were within limits. Both FDA and KEBS recommend that yeasts and mold count should be less than 100,000CFU/g in foods and these data support that these rice bran samples were within the recommended limit.

The cost of Mwea rice bran was lowest $(0.12-0.15 \mathrm{US} \$ / \mathrm{Kg})$ compared to RiBran 300 from the USA $(1.33-1.62 \mathrm{US} \$ / \mathrm{Kg})$. The price of the bran is also lower compared to maize in the Kenyan market, which retails at about $0.50 \mathrm{US} \$ / \mathrm{kg}$. This is an indicator that rice bran could be a sustainable food resource nutritionally and economically.

\section{Development of Novel Rice Bran Supplementary Foods}

Figure 1 shows the ingredients of the CSR blends (CSR1, CSR2, CSR3, CSR4, CSR5, CSR6 and CSR7) and their corresponding nutritional label. The rice bran content increased sequentially from CSR 1 ( $1 \mathrm{~g} / 125 \mathrm{~g}$ daily ration) to CSR7 $(30 \mathrm{~g} / 125 \mathrm{~g}$ daily ration), while reducing the maize portion of each formulation proportionately.
In $\mathrm{CSB}+$ and $\mathrm{CSB}++$ formulations, maize is currently used as a source of energy from carbohydrates, soya bean is included as a source of protein, vitamins and minerals, while sugar is incorporated to enhance flavour. In CSR formulations, rice bran does not only contribute energy from carbohydrates, but also provides important nutrients including dietary fibre, protein, fat, and minerals. Soya bean and sugar content remained constant in all CSR formulations. All of the ingredients were derived from whole grains to improve the dietary fibre content of the supplementary foods. A daily ration of $125 \mathrm{~g}$ CSR was found to provide a range of $448-461 \mathrm{kcal} /$ day, dietary fibre $9.1-13.1 \mathrm{~g} /$ day and $6.0-10.4 \mathrm{mg} /$ day of iron. All nutrients, except for energy and total carbohydrates, increased sequentially with increased rice bran content (Figure 1). These results show that rice bran is a major factor in influencing the final nutritional profile of CSR blends.

\section{Meeting the DRI with CSR Blends}

Figure 2 illustrates the fulfilment of Daily Recommended Intakes (DRI) by each of the food blends for MAM 12-24 month old children. The foods were modelled to fulfil at least $50 \%$ of daily energy requirement. Breastfed children will be targeted in this dietary intervention and are expected to obtain $39 \%$ of their daily energy from breastmilk, while the remaining should come from complementary foods $[28,41]$. It is also recommended that any supplementary food should provide at least $25 \%$ of the daily energy [42]. Since the children are malnourished, they will benefit from the high energy blends, which will increase their recovery. Even though $\mathrm{CSB}+$ and $\mathrm{CSB}++$ provided higher amounts of energy than the model rice-bran based blends, all CSR blends met the minimum condition for energy provision from other foods apart from breast milk.

Dietary fibre is a critical part of the diet, with regard to emerging research about enteropathy and gut health in the management of malnutrition. CSRs provide at least $50 \%$ of the DRI for dietary fibre for this age group and nutrition status. There are

Figure 1. Ingredients and nutrient composition of seven supplementary blends of $125 \mathrm{~g}$ with distinct corn, soya bean, rice bran doses for moderately malnourished 12-24 months old children.

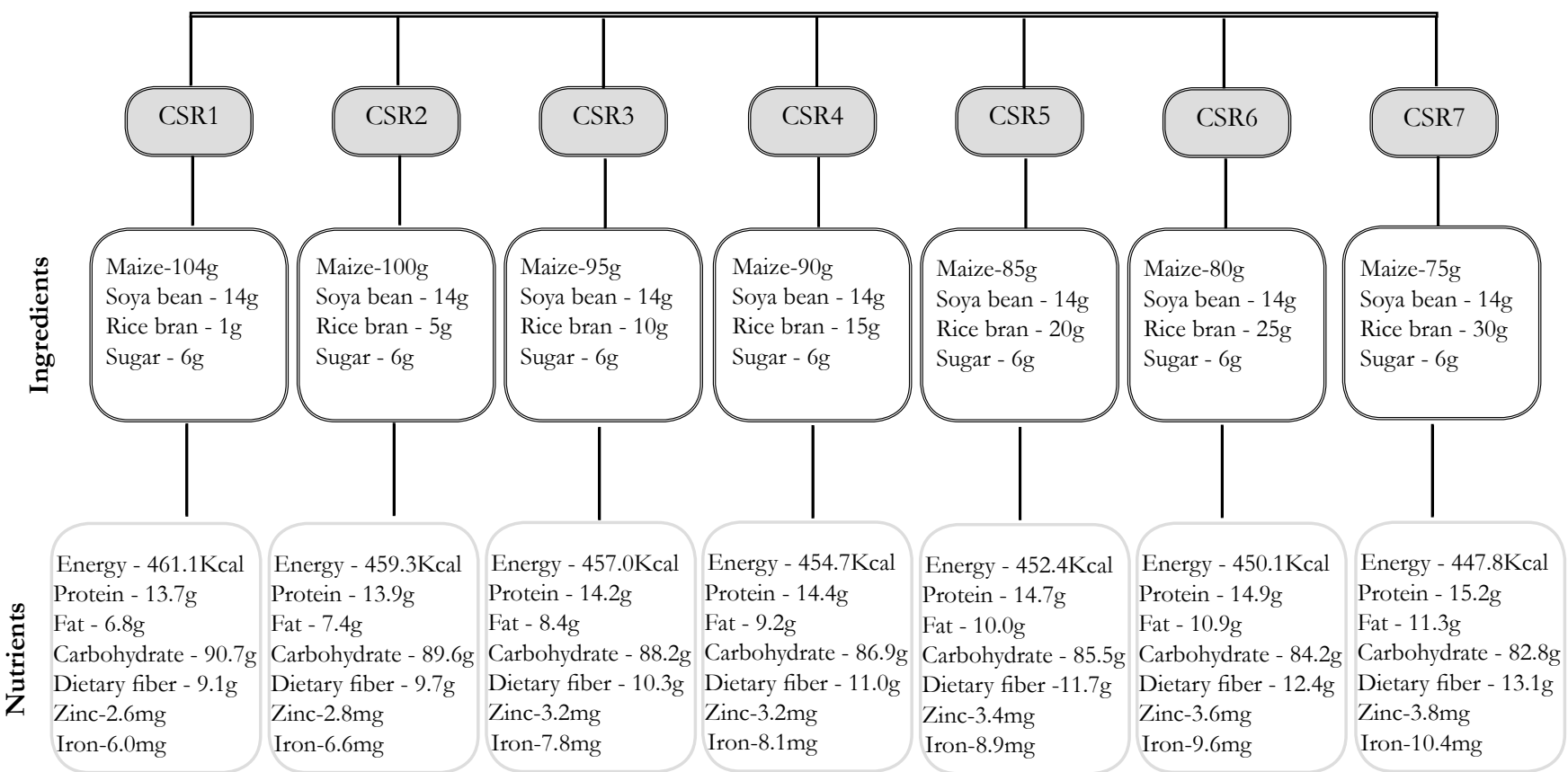


discrepancies in fibre recommendations from Codex Alimentarius who recommend that supplementary food for older infants should not exceed $5 \mathrm{~g} / 100 \mathrm{~g}$ of food $[30,31,42]$. CSR contains a range of $7.25-10.48 \mathrm{~g} / 100 \mathrm{~g}$ of dietary fibre per day from the supplementary food. However, the values still obtained from the foods only meet $47-69 \%$ of DRI. Due to the Codex Alimentarius restrictions, $\mathrm{CSB}+$ and $\mathrm{CSB}++$ achieve much less dietary fibre DRI. Iron and zinc are micronutrients of public health concern in the developing countries. CSR provides a range of $64.2-93.9 \%$ of zinc DRI and $100.7-173.2 \%$ of iron DRI. The DRI percent increases as the rice bran ratio increases. It is recommended that fortified food blends meet at least $75 \%$ of micronutrients [42] to prevent undernutrition. All blends, except CSR1, CSR2 and CSR3, met the minimum requirement for zinc and iron. CSB+ and $\mathrm{CSB}++$ are fortified with micronutrients, yet CSR4, CSR5, CSR6, and CSR7 provided more iron without extrinsic iron fortification. Rice bran can therefore be used as a source of iron and zinc, as well as energy, protein and fat for supplementary feeding in line with recommendation of WHO/UNICEF to use low cost, locally available foods to manage malnutrition [23].

There is dearth of information on how best to treat MAM in infants and young children in a cost effective way, especially among the consumers of cereal dominated diets [43]. This is due to in- adequate information on the nutritional adequacy of the foods as a result of the inherent anti-nutritional factors that may hinder bioavailability of some nutrients. There are arguments that the mineral bioavailability in cereal-based supplementary foods maybe lowered by anti-nutrients, such as phytates, due to its chelating effect on minerals $[29,41]$. To minimize this effect, some studies have shown improved micronutrient status upon dephytinization of cereal grains [44-46], addition of mineral absorption enhancers such as ascorbic acid [47], addition of animal source foods as enhancers of non-heme iron from cereals $[48,49]$ or micronutrient fortification [50, 51]. However, a systematic review identified large variations in absorption of iron between human studies signifying the need to further study the influence of phytates on minerals absorption if the findings of the studies are to be extrapolated to developing countries and to humans across the lifespan [52]. It is therefore necessary to determine the phytic acid content in the CSRs and further evaluate how the phytates from rice bran could influence the bioavailability of the minerals in the CSRs.

Figure 3 shows the proportion of energy that should be provided by each macronutrient in a food. All the foods fulfilled the requirement for carbohydrates and protein as recommended for 12 24 month old children. However, none of the CSR foods met the recommendation energy requirement from fat, which is proposed

Figure 2. Percentage of Daily Recommended Intake (DRI) by CSRs for moderately malnourished 12-24 month old children.

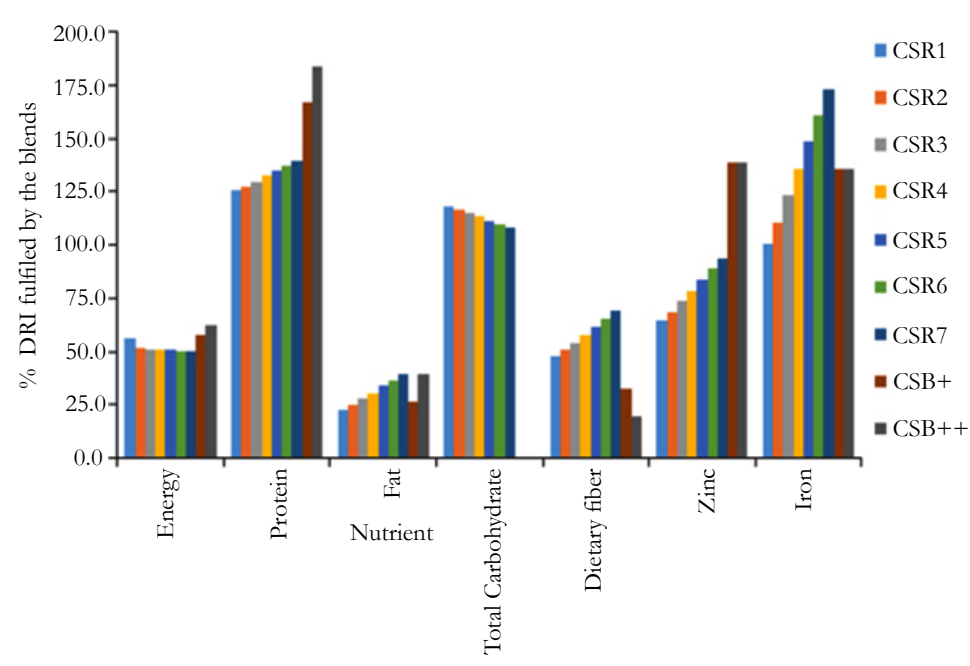

Figure 3. Proportion of energy provided by each of the macronutrients in the CSR blends compared to CSB + and CSB ++ .

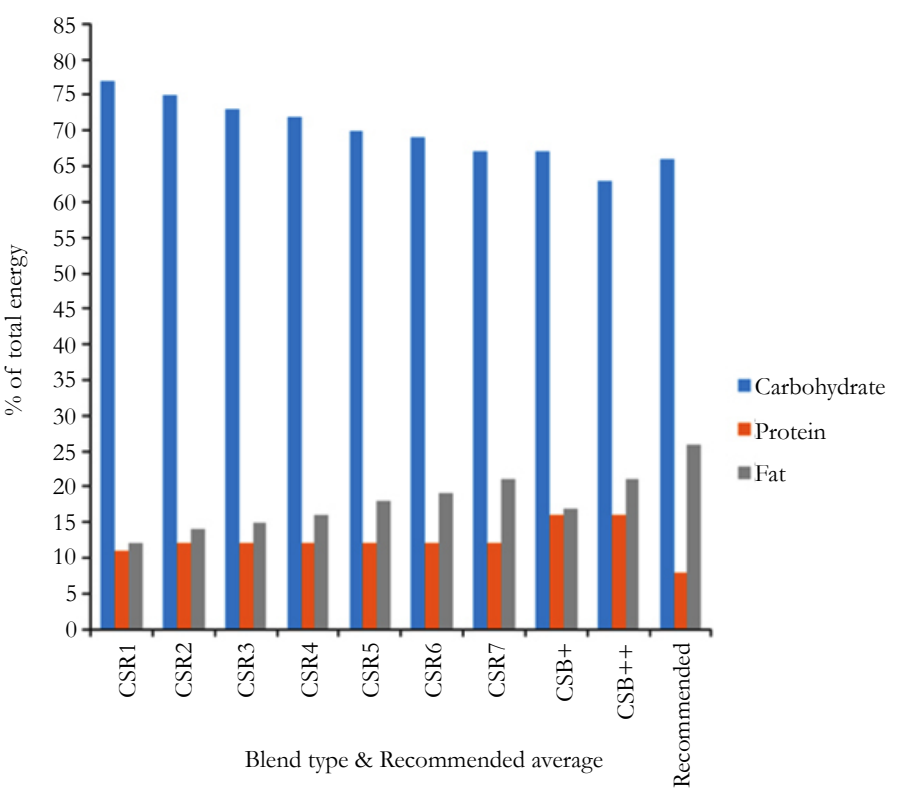


to be $24-28 \%$ of total energy [28]. The developed supplementary foods ranged from $12 \%$ in CSR1 to $21 \%$ in CSR7. CSB+ and $\mathrm{CSB}++$ achieved $17 \%$ and $21 \%$ of fat energy, respectively. Meeting this energy requirement is a challenge for a flour-based product since high fat content affects processibility, as well as the shelf life of the final blend. To achieve this recommendation, the caregivers would be encouraged to add margarine to the porridge when serving to the children. The oil can also be supplied separately from the flour and only added at consumption.

\section{Cost of the Blends}

The cost of CSR's was evaluated and compared to CSB + and $\mathrm{CSB}++$ (Figure 4). The ingredients' cost of CSRs ranged from $0.061 \mathrm{US} \$ / 125 \mathrm{~g}$ daily ration in CSR7 to $0.070 \mathrm{US} \$ / 125 \mathrm{~g}$ daily ration in CSR1. The retail costs of the blends also increased in a similar manner ranging between $0.092 \mathrm{US} \$ / 125 \mathrm{~g}$ daily ration and $0.105 \mathrm{US} \$ / 125 \mathrm{~g}$ daily ration. The retail cost of CSB + and CSB ++ was $0.171 \mathrm{US} \$ / 125 \mathrm{~g}$ daily ration and $0.306 \mathrm{US} \$ / 125 \mathrm{~g}$ daily ration. The retail cost of the CSR's was $65-70 \%$ lower than CSB++ and 38-46\% lower than CSB + supplementary foods available in Kenya. Vitamin/mineral micronutrient premix and skimmed milk powder are usually the major cost expenses in $\mathrm{CSB}+$ and $\mathrm{CSB}++$, which raised the total cost of ingredients and increased the retail cost of the foods. Rice bran is a low cost ingredient in the Kenya context. Rice bran could therefore be utilized to provide adequate nutrients at affordable costs to malnourished children.

Global food prices have been on the rise. The cost of staple foods such as maize have been affected [53] raising the cost of supplementary foods that are maize-based. There is therefore a need to substitute maize in dietary supplementary interventions to reduce malnutrition. Rice bran could be a possible alternative based on its current cost as evidenced by this study.

\section{Comparison of Rice Bran Blends and Maize Nutrient Con- tribution in the Blends}

This study showed that rice bran is nutrient dense and can be utilized as an ingredient in supplementary foods for MAM children. Maize is currently a major component of the supplementary foods. In Kenya, maize is one of the staple foods [6, 53, 54] and contributes the most significant amount of calories in this region [53] especially among young children. Together with soya bean, maize is the major ingredient in food-based strategies for management of acute malnutrition that has been supported by WFP. It is the main energy source, in addition to being a source of protein and fat. However, with a protein and fat of $9.42 \mathrm{~g} / 100 \mathrm{~g}$ and $4.74 \mathrm{~g} / 100 \mathrm{~g}$, respectively [34], maize is nutritionally inferior to rice bran. Therefore rice bran merits evaluation for partially replacing maize in processing of supplementary foods for management of malnutrition. White maize has lower amounts of calcium, iron and zinc compared to rice bran and hence presents an opportunity to incorporate rice bran in supplementary feeding. However, rice bran is lower in vitamins such as vitamin $C$ and vitamin $\mathrm{A}$, and so fortification maybe evaluated during food processing to achieve adequate levels for growth and development.

\section{Conclusion}

Rice bran was found to be a promising nutrient dense food ingredient with applications for MAM management. Rice bran provides adequate nutrients that are of public health concern to the developing countries such as zinc and iron. Rice bran based supplementary foods using Kenyan rice bran would provide adequate nutrients for MAM 12-24 month old children. Rice bran can be consumed throughout the life span and incorporated into supplementary foods at an affordable cost. Increasing consumption of rice bran during complementary feeding period merits further study for decreasing long-term malnutrition effects at an affordable cost. The efficacy of the blends on the prevention or treatment of MAM in children needs to be evaluated.

\section{Acknowledgement \& Declarations}

The authors would like to acknowledge the support of CSU

Figure 4. Cost estimates of the formulated CSR blends compared to CSB+ and CSB++.

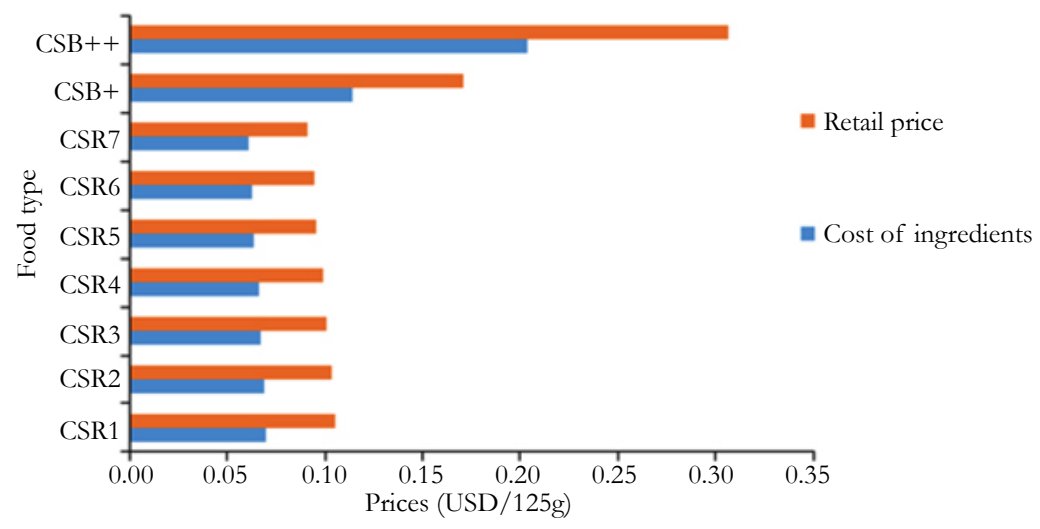

Agroecosystems Fellowship and a Grand Challenges Explorations in Global Health award from Bill and Melinda Gates Foundation (OPP1043255) for rice bran analysis.

\section{References}

[1]. Borresen EC, Ryan EP (2014) Rice bran: A food ingredient with global public health opportunities. Wheat Rice Dis Prev Health 301-310.

[2]. Sheflin AM, Borresen EC, Wdowik MJ, Rao S, Brown RJ, et al. (2015) Pilot dietary intervention with heat-stabilized rice bran modulates stool microbiota and metabolites in healthy adults. Nutrients 7(2): 1282-1300.

[3]. FAO (2014) FAO Rice Market Monitor. Rome.

[4]. FAO (2013) FAO Rice Market Monitor. Rome.

[5]. Saito K, Dieng I, Toure AA, Eklou attiogbevi-somado, Wopereis MCS (2015) Rice yield growth analysis for 24 African countries over 1960-2012. Glob Food Sec 5: 62-69.

[6]. National Cereals and Product Board (2015) Rice. http://www.ncpb.co.ke/ index.php?option=com_content\&task=view\&id=31\&Itemid=46.

[7]. Short C, Mulinge W, Witwer M (2012) Analysis of incentives and disincen- 
tives for rice in Kenya. Technical notes series. MAFAP, FAO, Rome.

[8]. Halder D, Bhowmick S, Biswas A, Mandal U, Nriagu J, et al. (2012) Consumption of brown rice: A potential pathway for arsenic exposure in Rural Bengal. Environ Sci Technol 46(7): 4142-4148.

[9]. Cai H, Al-Fayez M, Tunstall RG, Platton S, Greaves P, et al. (2005) The rice bran constituent tricin potently inhibits cyclooxygenase enzymes and interferes with intestinal carcinogenesis in ApcMin mice. Mol Cancer Ther 4(9): 1287-1292.

[10]. Kahlon TS (2009) Rice bran: Production, composition, functionality and food applications, physiological benefits. CRC Press, Taylor \& Francis group, NW. 305-321.

[11]. Bhatnagar AS, Prabhakar DS, Prasanth Kumar PK, Raja Rajan RG, Gopala Krishna AG (2014) Processing of commercial rice bran for the production of fat and nutraceutical rich rice brokens, rice germ and pure bran. LWT - Food Sci Technol 58(1): 306-311.

[12]. KNBS (2014) Kenya demographic and health survey: Key indicators. Nairobi.

[13]. Patel S (2015) Cereal bran fortified-functional foods for obesity and diabetes management: Triumphs, hurdles and possibilities. J Funct Foods 14: 255-269.

[14]. Forster GM, Raina K, Kumar A, Kumar S, Agarwal R, et al. (2013) Rice varietal differences in bioactive bran components for inhibition of colorectal cancer cell growth. Food Chem 141(2): 1545-1552.

[15]. Henderson AJ, Kumar A, Barnett B, Dow SW, Ryan EP (2012) Consumption of rice bran increases mucosal Immunoglobulin A concentrations and numbers of intestinal Lactobacillus spp. J Med Food 15(5): 469-475.

[16]. Komiyama Y, Andoh A, Fujiwara D, Ohmae H, Araki Y, et al. (2011) New prebiotics from rice bran ameliorate inflammation in murine colitis models through the modulation of intestinal homeostasis and the mucosal immune system. Scand J Gastroenterol 46(1): 40-52.

[17]. Yang X, Wen K, Tin C, Li G, Wang H, et al. (2014) Dietary rice bran protects against rotavirus diarrhea and promotes Th1 type immune responses to human rotavirus vaccine in gnotobiotic pigs. Clin Vaccine Immunol 21(10): 1396-1403.

[18]. Gordon JI, Dewey KG, Mills DA, Medzhitov RM (2012) The human gut microbiota and undernutrition. Sci Transl Med 4(137): 1-6.

[19]. Richard SA, Mccormick BJJ, Miller MA, Caulfield LE, Checkley W, et al. (2014) Modeling environmental influences on child growth in the MAL-ED Cohort Study: Opportunities and challenges. Clin Infect Dis 59(Suppl 4): 255-260.

[20]. Fuchs G, Ahmed T, Araya M, Baker S, Croft N, et al. (2004) Malnutrition: Working Group report of the second World Congress of Pediatric Gastroenterology, Hepatology, and Nutrition. J Pediatr Gastroenterol Nutr 39(Suppl 2): S670-S677.

[21]. Prendergast AJ, Rukobo S, Chasekwa B, Mutasa K, Ntozini R, et al. (2014) Stunting is characterized by chronic inflammation in zimbabwean infants. PLoS One 9(2): e86928.

[22]. Ngure FM, Reid BM, Humphrey JH, Mbuya MN, Pelto G, et al. (2014) Water, sanitation, and hygiene (WASH), environmental enteropathy, nutrition, and early child development: Making the links. Ann N Y Acad Sci 1308: 118-128.

[23]. WHO/UNICEF (2003) A new global strategy for infant and young child feeding.

[24]. Wang RJ, Trehan I, LaGrone LN, Weisz AJ, Thakwalakwa CM, et al. (2013) Investigation of food acceptability and feeding practices for lipid nutrient supplements and blended flours used to treat moderate malnutrition. J Nutr Educ Behav 45(3): 258-263.

[25]. Pencharz PB (2010) Protein and energy requirements for "optimal" catch-up growth. Eur J Clin Nutr 64(Suppl 1): S5-S7.

[26]. Joint FAO \& World Health Organization (2005) Vitamin and mineral requirements in human nutrition. Geneva.

[27]. Joint FAO \& World Health Organization (2004) Human energy requirements. Rome.

[28]. Lutter CK, Dewey KG (2003) Proposed nutrient composition for fortified complementary foods. J Nutr 133(9): 3011S-3020S.

[29]. Daelmans B, Martines J, Saadeh R (2003) Special Issue Based on a World Health Organization Expert Consultation on Complementary Feeding. Food Nutr Bull 24(1): 5-29.

[30]. WFP (2014) Technical Specifications for the manufacture of super cereal - Corn Soya Blends (CSB+). http://documents.wfp.org/stellent/groups/public/documents/manual_guide_proced/wfp251131.pdf.

[31]. WFP (2014) Technical Specifications for the manufacture of super cereal plus - Corn Soya Blend (CSB++). http://documents.wfp.org/stellent/groups/ public/documents/manual_guide_proced/wfp262697.pdf.

[32]. Kinyuru JN, Konyole SO, Onyango-Omolo SA, Kenji GM, Onyango CA, et al. (2015) Nutrients, functional properties, storage stability and costing of complementary foods enriched with either termites and fish or commercial micronutrients. J Insects as Food Feed 1(2): 149-148.

[33]. Owino VO, Sinkala M, Amadi B, Tomkins AM, Filteau SM (2007) Acceptability, storage stability and costing of $\alpha$-amylase-treated maize-beansgroundnuts-bambaranuts complementary blend. J Sci Food Agric 87(6): 1021-1029.

[34]. USDA (2015) National Nutrient Database for Standard Reference Release 27. http://ndb.nal.usda.gov/ndb/search/list.

[35]. WHO/FAO/UNU (2007) Joint FAO/WHO/UNU Expert Consultation on Protein and Amino Acid Requirements in Human Nutrition. Geneva, Switzerland.

[36]. FAO/WHO (2004) Joint FAO/WHO Expert Consultation on Human Vitamin and Mineral Requirements in Human Nutrition. Bangkok, Thailand.

[37]. Layrisse M, García-Casal MN (1997) Strategies for the prevention of iron deficiency through foods in the household. Nutr Rev 55(6): 233-239.

[38]. Kwena AM, Terlouw DJ, de Vlas SJ, Phillips-Howard PA, Hawley WA, et al. (2003) Prevalence and severity of malnutrition in pre-school children in a rural area of western Kenya. Am J Trop Med Hyg 68(4 Suppl): 94-99.

[39]. Carey M, Jiujin X, Gomes Farias J, Meharg AA (2015) Rethinking Rice Preparation for Highly Efficient Removal of Inorganic Arsenic Using Percolating Cooking Water. PLoS One 10(7): e0131608.

[40]. Sun GX, Williams PN, Carey AM, Yong-Guan Z, Deacon C, et al. (2008) Inorganic arsenic in rice bran and its products are an order of magnitude higher than in bulk grain. Environ Sci Technol 42(19): 7542-7546.

[41]. Golden MH (2009) Proposed Recommended Nutrient densities for moderately malnourished children. Food Nutr Bull 30(3 Suppl): S267-342.

[42]. Fleige LE, Moore WR, Garlick PJ, Murphy SP, Turner EH, et al. (2010) Recommendations for optimization of fortified and blended food aid products from the United States. Nutr Rev 68(5): 290-315.

[43]. Michaelsen KF, Hoppe C, Roos N, Kaestel P, Stougaard M, et al. (2009) Choice of foods and ingredients for moderately malnourished children 6 months to 5 years of age. Food Nutr Bull 30(3 Suppl): S343-404.

[44]. Egli I, Davidsson L, Juillerat MA, Barclay D, Hurrell RF (2002) The Influence of Soaking and Germination on the Phytase Activity and Phytic Acid Content of Grains and Seeds Potentially Useful for Complementary Feed-in. J Food Sci 67(9): 3484-3488.

[45]. Hurrell RF, Reddy MB, Juillerat MA, Cook JD (2003) Degradation of phytic acid in cereal porridges improves iron absorption by human subjects. Am J Clin Nutr 77(5): 1213-1219.

[46]. Egli I, Davidsson L, Zeder C, Walczyk T, Hurrell R (2004) Dephytinization of a complementary food based on wheat and soy increases zinc, but not copper, apparent absorption in adults. J Nutr 134(5): 1077-1080.

[47]. Davidsson L (2003) Approaches to improve iron bioavailability from complementary foods. J Nutr 133(5 Suppl 1): 1560S-1562S.

[48]. Skau JKH, Touch B, Chhoun C, Chea M, Unni US, et al. (2015) Effects of animal source food and micronutrient fortification in complementary food products on body composition, iron status, and linear growth : a randomized trial in Cambodia. Am J Clin Nutr 101(4): 742-751.

[49]. Bwibo NO, Neumann CG (2003) Animal source foods to improve micronutrient nutrition and human function in developing countries. J Nutr 133: 3936S-3940S.

[50]. Adu-Afarwuah S, Lartey A, Brown KH, Zlotkin S, Briend A, et al. (2008) Home fortification of complementary foods with micronutrient supplements is well accepted and has positive effects on infant iron status in Ghana. Am J Clin Nutr 87(4): 929-938.

[51]. Owino VO, Kasonka LM, Sinkala MM, Wells JK, Eaton S, et al. (2007) Fortified complementary foods with or without $\alpha$-amylase treatment increase hemoglobin but do not reduce breast milk intake of 9-mo-old Zambian infants. Am J Clin Nutr 86(4): 1094-1103.

[52]. Collings R, Harvey LJ, Hooper L, Hurst R, Brown TJ, et al. (2013) The absorption of iron from whole diets: a systematic review. Am J Clin Nutr 98(1): 65-81.

[53]. FAO (2014) FAO statistical year book. (2nd edtn), FAO Regional Office for Africa, Accra, Ghana.

[54]. Mason NM, Jayne TS, Chapoto A, Donovan C (2011) Putting the 2007/2008 global food crisis in longer-term perspective: Trends in staple food affordability in urban Zambia and Kenya. Food Policy 36(3): 350-367. 